\title{
Representation of Latvia and Latvians in Contemporary Latvian Literature
}

\author{
MAIJA BURIMA \\ Institute of Comparative Studies, Daugavpils University, Vienibas Str. 13 - 318, Daugavpils, Latvia \\ E-mail: maija.burima@du.lv
}

\begin{abstract}
Concepts 'Latvia' and 'Latvians' in literature are more closely than others related to tendencies of culture policy and historical and socio-economic changes. In Latvian literature there are not so many texts focusing on the Latvian nation and state as a phenomenon.

The article regards representations of the national / state identity as the central strategic manifestations in contemporary Latvian literature. This strategy gets activated in complicated or dramatic moments of the history for the nation / state. Recent Latvian literature brings out the representation of two identity aspects: personal identity - individual self-perception based on one's physical, intellectual, and moral peculiarities; group or social identity - individual self-characteristics based on belonging to particular social groups - ethnic, professional, etc. Within one literary work just one identity aspect may be represented but they may also overlap.

At the turn of the first and second decades of the 21 st century a number of texts were published with titles foregrounding the lexical units "Latvians", "we" or some significant signs of the national culture. Aspects of the collective identity are widely discussed in several works of fiction the titles of which suggest common social and mental structures of contemporary Latvian population as preconditions for the existence of identity communities.

The texts analyzed in the paper include Kārlis Vērdiņšs poetry prose collection "Es" [I] (2008), Guntars Godiņšs poetry collection “CV”, Nora Ikstena’s sketch "Par mums" [On Us] (2009), Vilis Lācìtis's novel "Strojka ar skatu uz Londonu" [Construction Site with a View of London] (2010), Otto Ozols's novel "Latvieši ir visur" [Latvians are Everywhere] (2010).
\end{abstract}

Key words: identity, personal identity, collective identity, Latvia, Latvians

\section{INTRODUCTION}

The present article addresses transformations of identity depiction in contemporary Latvian literature in the context of topical social and culture processes. It regards two identity structures: the personal (individual) and collective. The following components of the associative field of the concept 'identity' used in the titles or texts of literary works are selected as 
indicators of representation of both identity structures: "I", "CV”, "Latvian", “we”, "Latvians", "Latvia".

In the middle of the twentieth century, the economic and political life of Latvia had reached certain stability that functioned as a stimulus for individuals to demonstrate their uniqueness and reflect their individual experience in public that differed from the interpretation of the collective history or public stereotypes. This strategy is used in two collections of poetry published in 2008 by the modernist poets Guntars Godiņ̌s ("CV”) and Kārlis Vērdiņš ("Es").

The global economic crisis that started by the end of the first decade of the $21^{\text {st }}$ century affected almost all social groups. Common problems were the basis for individuals to draw closer on the basis of the collective identity. The latter was searched in belonging to people and state, in echoes of the preceding historical stages (empire, first independence, and soviet times) and contemporary social tendencies: urbanization, technologization, globalization, economic migration.

The article regards representations of the national / state identity as the central strategic manifestations in contemporary Latvian literature. This strategy gets activated in complicated or dramatic moments of history for the nation / state. At the turn of the first and second decades of the 21 st century a number of texts were published with titles foregrounding the lexical units "Latvians", "we" or some significant signs of the national culture. Aspects of the collective identity are widely discussed in several works of fiction the titles of which suggest common social and mental structures of contemporary Latvian population as preconditions for the existence of identity communities.

\section{CONCEPTS 'LATVIA' AND 'LATVIANS' IN LATVIAN LITERATURE: EMPIRICAL, HISTORICAL AND THEORETICAL BACKGROUND}

In the range of the canonized topics of each national literature, an essential place is attributed to motifs that form its national, state, and ethnic concepts.

Each individual assigns significance and categorizes the environment s/he lives in, thus forming certain mental structures by means of points of reference. In a wider context - different individuals form communities based on common invariant structures - points of reference - and thus, being aware of belonging to them, develop the identity of the corresponding community that in a wider sense is manifested in national identity (1).

In Latvian literature there are not so many texts focusing on the Latvian nation and state as a phenomenon. Among exemplary texts of this kind one must mention the German writer Garlībs Merk̦elis’ historical work "Latvieši” (1796) [Latvians], Vizma Belševica’s poem "Indriḳa Latvieša piezīmes uz Livonijas hronikas malām” [Henricus Lettus' Notes on the Margins of Livonian Chronical] in the book of poems "Gadu gredzeni" [Annual Rings] (1968). More often writers used the image of Latvia in various historical and social contexts and genres, e. g. journalism. Kārlis Skalbe in his book "Mazās piezīmes" [Small Notes] (1920), Edvarts Virza in his poetry, Jānis Akuraters in his collection "Latvijas balādes" [Latvian Ballads] (1922), Vilis Plūdonis, Leonīds Breikšs, J. Jaunsudrabiņš when being in exile wrote his essay "Piemini Latviju" [Remember Latvia], etc. The writer Rutku Tēvs in the novel "Latvietis un vina kungs" (Latvian and His Master, first published in 1932-1933) depicts the fight of Latvian peasants for their rights at the beginning of the 19th century, while Alberts Bels individualizes the problems of the average Latvian at the time of Soviet

(1) $[12,4]$. 
occupation and nowadays in his novel "Latvie u labirints" (Latvian Labyrinth). The collective, state, or national identity occurs even more seldom in children's literature. One of recent examples is found in the book for children "Latviešu zvēri" (Latvian Beasts, 2009) by Inese Zandere and Mārtiņš Grauds. It entails five stories depicted in photo illustrations. The authors aim at supplanting the early impressions gained by children in the course of their personality development provided by books by images corresponding to the environment of Latvia and its mentality, not just any coloured pictures.

Concepts 'Latvia' and 'Latvians' in literature are more closely than others related to tendencies of culture policy and socio-economic changes. Their intense use is related to the time of national independence in the interbellum period and after the restoration of the Latvian statehood in 1991. Changes conditioned by national awakening in the society concerned literature with a certain shift in time as many writers worked in the regime of onlooking and accumulating the unfamiliar experience of the West. However, the literary space did not remain vacant. Essential changes in the Latvian literature took place after 1991: interest in previously forbidden and silenced authors' works (including the literature of exile and forbidden foreign authors); integration of Western European literature traditions.

In Latvia, literary phenomena that had developed gradually in the West were integrated in an 'unprepared soil' and caused provocative reaction, e. g. postmodernism, poststructuralism, feminist criticism, gender studies. These culture forms and critical approaches appeared both in the late twentieth-century Latvian fiction and the analysis and interpretation of literary texts.

Twenty years have passed since the restoration of the Latvian statehood. In the interbellum period the Republic of Latvia had existed for 22 years. Hence, both periods of time are chronologically similar, yet the poetic scope of the "Golden age" of Latvian literature of the 1920-30s has not been reached by the contemporary literature either quantitatively or qualitatively. This may be accounted for by the peripheral status of literature among other means of communication. Yet also in the literature of recent decades innovative experiments have occurred and writers have tried to react to urgent public discussions. Major themes and motifs in the early twenty-first century Latvian literature are as follows: Latvia and Latvians in the aspect of identity / identification; memoir literature (autobiography, memory narratives and sketches, memoirs, documentary novels, etc. that foreground the poetics of memory); sacred thematics (not so much present in the Latvian literature on the whole, but the situation of crisis intensifies the use of this motif), e. g. prose books: Gundega Repše "Stāsti par mācekḷiem" (Tales of Disciples, 2009), Nora Ikstena "Šokolādes Jēzus" (Chocolate Jesus, 2009); globalization features (internet as a chronotope, concept of photography, mobile phone, cheap airlines, etc.); animal imagery as an indication to humans' inability to communicate substituted by refocusing of attention towards the animal world.

\section{THE REPRESENTATION OF PERSONAL IDENTITY IN COMPARATIVE LATVIAN LITERATURE}

Personal identity is the most solid one and is a precondition for all others. Personal identity is most saturated semantically and is most directly rooted in the categorization processes based on one's bodily experience and perception; it is a totality of meanings that manifests relative stability of individual as a self; these meanings function, are modified and preserved in various social contexts and social roles assuming that social role identities at least partially overlap with person identities (2).

(2) $[12,8]$. 
The opportunities offered to people by the post-iron curtain age in the literature of the last decade of the twentieth century and the first decade of the twenty-first century are realized as narratives of experience that form an individual as a unique being. This literary strategy is welcomed also by the background of the epoch - material welfare and its promised opportunities of cultural communication in the most diverse manifestations. These trends of the epoch in literature are brought out in the Kārlis Vērdiņš poetry prose collection "Me" (Es, 2008) and the Guntars Godinš poetry collection "CV" (2008). The Vērdinšs collection reveals the experience of the formation of poet's personality - his life and academic schools and universities, learning about culture layers of different ages, his opinion about various historical processes and topicalities of the epoch. The basic intonation of the collection is self-irony and carnivalization. Vērdiņš foregrounds various traditional and modern culture codes demonstrating the way collective stereotypes settle in the individual's consciousness and evolve in a new attitude towards the processes of social and culture life in Latvia.

Godiņš has dedicated his poetry collection "CV" to his own 50th anniversary. It comprises 2 parts. The former includes poems of the Soviet period with the idea of spiritual opposition. Being one of the most significant poets who entered the literary scene in the 1980s, Godin̄š, though he has recently written and published very little, may be considered as an epitome of the fact that, over the last 30 years along with the political events, changes in society and human thinking, poetry has changed as well. Godinšs is one of the 'angry young men' of the 1980s - a disciple of the 'informalists' of the '70s Knuts Skujenieks, Uldis Bērziñš, Jānis Rokpelnis, in the '80s he wrote many a poem rich in subtext, ironic quarts on the pompous absurdity of the Soviet power, brainwashing and deformation of human personality practised by it. The scathing tone of the Soviet period was not demanded in the situation of an independent country and it took a long time for the poet to find a new poetic expression. The poetry produced with it makes up the second part of the collection - within almost ten years of post-awakening period Godinšs had formed a new style with acoustic poetic tricks and chains of original metaphors.

Collections by G. Godinšs and K. Vērdiņš demonstrate the poets' desire of personal insight, realization of one's personality segments, indicating differences that make them unique among other individuals.

\section{THE REPRESENTATION OF COLLECTIVE IDENTITY IN COMPARATIVE LATVIAN LITERATURE}

In recent years the stability of all kinds has rapidly changed in the global world both in the economic and ethnical as well as geopolitical aspects. This situation of a loss of the basis experienced by an individual provokes writers to search for stable values that would create in people a sense of security, stability, and identification. Sigma Ankrava has noted that In the contemporary world struck by globalization, awareness and preservation of one's identity is one of the most topical problems (3).

Essential feature of recent literature is the writers' interest in the concepts 'Latvia' and 'Latvians'. Texts related to the representation of these concepts characterize two aspects of identity: personal identity - individual self-perception based on one's physical, intellectual, and moral peculiarities; group or social identity - individual self-characteristics based on belonging to particular social groups - ethnic, professional, etc. Within one literary work just one identity aspect may be represented but they may also overlap. Stuart Hall suggests

(3) $[1 ;$ http://www.tautasforums.lv/?p=1272] 
to regard national culture as a discourse that affects actions of the members of a nation and their self-conception. National culture constructs identities creating meanings of a nation whereby people can identify. It includes stories and memories that unite the past of a nation with its present as well as images created in the culture of the nation (4). Norwegian anthropologist Thomas Hylland Eriksen in his book "Roots and Foots. Identity in a Changing Time" (2010) describes psychological mechanisms that affect the fluctuations of personal and collective identity sensations in individuals:

There are not many universal notions about the existing groups. 'Sex' and 'age' are two notions, 'we and those others' if the third. It seems that there are no more. $<\ldots>$ How does this powerful 'we' come about? Common experience, language, and religion help, yet these are not enough. The anatomy - whether we talk about sex or the colour of skin - helps, yet it is not enough at all. Common place of living helps but again - more is needed. If there is also a common project, a goal for future where the contribution of other group members matters in my success, this is of great help. And if besides one can refer to a common foe, other who threatens to destroy one's plans, then everything is prepared for powerful sense of "us" based on solidarity that endures until it is possible to remind oneself of the foe and preserve the flame of hope burning. When the project is fulfilled, the sense of "us" grows weaker but it may glow until the group members preserve the attitudes of duty and mutual necessity. If foe becomes uncertain, the sense of "us" is lost as wel (5).

In a situation when the socio-economic stabilization of recent years has been rapidly replaced by the sense of crisis, dissatisfaction roused by it needs a concrete enemy. This enemy is searched in the global economic institutions like the World Bank, International Monetary Fund that have given huge credits, EU bureaucracy that impedes the development of the Latvian economy by complicated directives. Ieva Raubi ko in a paper dedicated to the day of Europe has noted concerning the sense of Europe in Latvians:

Do our people feel like Europeans? In my opinion, two planes should be differentiated here: the material and the conceptual. Europe is present materially, tangibly in various places of Latvia... $<\ldots>$ You may say that here is a rift between the material and the conceptual: Europe for Latvian people, especially those who live in the countryside, is not the space of ideas and living to share with other Europeans. As becomes obvious in the countryside, 'Europe' is rather the EU money and related rules and control. Europe is still a foreign body, external factor, "another union" that may be used for both good and useful matters and blame for failures and undesirable processes (6).

In the fiction of two recent years, writers have started using the collectively uniting pronoun "we, us" more profusely, both in the titles of works and implicitly, thus introducing the sense of collective identity in the text content: we - Latvians, we - Latvians who live outside Latvia as economic émigrés, we - residents of Latvia. The dual character of Latvia and Latvians is outlined in Nora Ikstena's sketch "About Us" (Par mums) in the collection "Chocolate Jesus" (Šokolādes Jēzus, 2009).

If I need to tell about Latvia, first I have to think about my own moments of communicating with my native land. Different scenes enter my mind. Kilometers long sandy beach and a line of horizon that joins the sky with the earth. Ruined houses outside cities, debris of the Soviet army military objects in woods, heaps of garbage here and there. Posh villas surrounded

(4) $[5,595-634]$.

(5) $[4,65-66]$.

(6) $[10,4]$. 
by high fences with signalization systems and shabby wooden shanties guarded by faithful mongrels. The solitary profound silence of country graveyards and the collectiveness of new developments erected in Soviet times. Well-off, dressed-up lucky men in Old Riga, beggars and street musicians around the Statue of Freedom, drunkards of Maskačka. <...> The unified assortment of supermarkets, fresh strawberries on the highroad sides in June and smoked flukes in seaside villages in August (7).

The small sketch by Ikstena precisely outlines the contrasts of the Latvian society sympathizing with the local, specific, anti-global signs.

Great resonance in the Latvian literary space was caused by the novel "Latvieši ir visur" (Latvians are Everywhere) by Otto Ozols (real name Mārtiņš Barkovskis) published in 2010. If from the artistic point of view the novel caused skepticism in critics, the readers reacted with positive discussions and the novel became a local best-seller. This was conditioned by the intriguing subtitle with a connotation of collective identity - "The first Latvian global thriller" and the motto of the novel: "Medicine for raising the self-assurance of Latvians". (It seems that since the Garlieb Merkelis' publication of Latvians in 1796 none of Latvian writers had ever used the word 'Latvians' in a book title, besides, Merkelis was not Latvian but a Baltic German writer and publicist). The novel provides exciting information on Latvian celebrities with world fame in different times as well as on common people endowed with great industriousness who became outstanding in their life. Ozols writes: It is not that Latvians were kind of superhumans. No way. Yet in the world context the number of outstanding Latvians is disproportionally high (8). In the novel the notion 'Latvians' is made wider. It denotes everybody having any relation with the territory of Latvia: those who were born in Latvia, ethnic Latvians, Latvian Jews, Russians. The author studies the impact of these people on the historical, political, cultural, everyday life and other processes.

The author of "Latvieši ir visur" pretends to be a character of the novel positioning himself as an émigré who managed to escape from the USSR and get a refugee status in Denmark shortly before regaining of independence of Latvia. Richard whom he meets by chance in Berlin (already after the dismantling of the wall) seems to greatly affect his further life. The author becomes a courier in an international agency carrying important papers and big sums of money from one state to another. The central character of the book stands beside Kissinger and Putin who are also surprised at Latvians being everywhere. Ozols characterizes the impulses of writing the novel as follows:

At the end of the 1990s I was in Finland, and Latvia as usual had made a kind of international mess. The name of Latvia appeared in the papers high and low. One of my Finnish acquaintances told me: "You Latvians get into problems easily." "Don't you? Everyone does, Estonians do, Latvians do as well..." The Finn said: "You know, everyone gets into a problem now and then but Latvians manage to do it more often than others." I started thinking about this matter, read and compared problematic occurrences with Latvia and Latvians in the twentieth century and came to the conclusion that the rate of Latvians getting involved in global scandals or tried to change history is unnaturally high. I started looking into it more carefully - not through the lens of Latvian historian or journalists but taking books of history written by foreign authors who did not have direct relation to Latvia and that were not addressed to Latvian readership. They also insistently mention Latvians to this or that occasion - and

(7) $[6,28-29]$.

(8) $[9,220]$. 
more than other small nations. I realized that there is a phenomenon beneath that cannot be logically explained. Wherever you turn, you always face a Latvian. I talked to a friend that these things should be pieced together (9).

The narrative strategy of Ozols' novel "Latvians Are Everywhere" based on thorough studies of Latvian and world little known historical events proved to be matching the emotional mood of the Latvian community of 2010 as it was aimed at constructing the collective identity and consolidating national self-awareness.

Great shift of Latvian residents' place of living and lifestyle and the formation of a related subculture are depicted in Vilis Lācītis' (real name Aleksandrs Rug̣ēns) novel "Stroika ar skatu uz Londonu" (Construction Site with a View of London) [2010] (the writer's pseudonym is an ironic diminutive form of the name of a notorious Soviet literary icon and collaborationist Vilis Lācis: "Lācis was a classic, I could be a small classic", the writer ironically states) (10). The novel is another sensation of the Latvian literature of 2010 that was called in reviews the greatest surprise of 2010 of the rather predictable and sleepy Latvian literature (11).

The narrator of the novel is a young man who works in construction. The plot of the novel is based on a criminal intrigue along with ironic and good-humoured judgements on Latvia and England, Latvians and immigrants based on serious reflection.

Having lived almost 10 years in UK, V. Lācītis has learnt to look at Latvians from aside, and his observations are quite harsh.

When I now visit Latvia and observe everything that is going on there through a different lens seeing those numerous protests, it struck me home that the attitude in Latvia is such that the decaying West is coming and destroying our moral values - imposing homosexuality, drugs, violence, mass production, strangling Latvian agriculture. What everybody is defending now in Latvia is in fact Soviet moral values that we have grown up with. Fifty years in the Soviet Union - the fairest minds have been killed, deported, or emigrated. $<\ldots>$ To a certain extent, Latvian is characterized by Stroika [construction site]. More precisely, by Latvian's conduct when s/he is among Polish, Lithuanians, Ukrainians and other nationalities who are considered to those who experienced the Soviet times to be more familiar than British in whose land these East Europeans have come to make living. And they all are united by refusing to learn English as it is possible to do without it in the everyday life, being among one's own people both at work and at home (12).

In numerous internet publications and commentaries on this book readers agree on the recognition of the topical content of the book. One of the peculiarities of V. Lācitis' text is the stylization of guest workers' speech by means of many English and Russian slangy and jargon words. They along with the painful and widely debated topic of the mass economic emigration of people from Latvia create the effect of identification in many readers and, emphasizing the features characteristic of the Soviet generation on the whole, unite those who live in Latvia with Latvian guest workers in other countries.

(9) [3; http://berelis.wordpress.com/2010/08/18/kokteilis-kas-ir-spradzienbistams-saruna-ar-otto-ozo$\mathrm{lu} /]$

(10) [2; http://www.kasjauns.lv/lv/zinas/35026/latviesu-viestradnieks-londona-uzraksta-kulta-romanu]

(11) [7; http://zinas.nra.lv/izklaide/33149-vilis-lacitis-un-latvju-leibors.htm]

(12) [11; http://www.diena.lv/izklaide/skatuve/pirmizrade-vila-lacisa-romana-stroika-ar-skatu-uz-londonu-iestudejumam-774554] 
My instinct of being the chased East European who suspects all, guest worker and illegal worker was solid as a rock, it resided in the very core of my soul, if I may say so (13).

I represent the generation that can clear the construction debris no matter where - in Sorbonne or Cambridge, it cannot change the inner level of our education. Our first, instinctive reaction still remains, "What do you want from me?" or "Why me?" or of the kind. We start when a passenger looking like a ticket controller enters a carriage - no matter whether we have the ticket or no. We, the émigrés, are in a way a pack of milksops: we could do no good in our homeland and so we are searching our fortune elsewhere. But what a school of survival we have passed through! If Latvia were a bottle of champagne we would be like a cork and our life - the one shaking the bottle. <...> Not everyone will remain outside Latvia, no worry about that. However, those who will return will see the life from a different angle. And it will be the true globalization. Cultural and mental changes - not imposed from aside but desired from inside (14).

The text of the novel was taken as the basis for a monoperformance of Mārtiņš Eihe that was staged soon after the publication of the novel in the stand-up format in many towns of Latvia. The authors of the performance point out that it was produced with the hope that the audience would at least consider the question about leaving or staying in Latvia.

The book received the Annual Literary Prize of 2010 in the nomination of readers' vote. Criticism about the Lācitis' book, like about that of Ozols, is reserved or skeptical.

The latest edition in the Latvian fiction emphasizing the collective identity is the collection of stories "Mēs. XX gadsimts" [We. Twentieth Century]. It has been produced with the initiative of Gundega Repše by the 12 most famous contemporary Latvian women writers: Ilze Jansone, Inga Žolude, Andra Neiburga, Kristine Želve, Ieva Melgalve, Andra Manfelde, Dace Rukšāne, Nora Ikstena, Gundega Repše, Inga Ābele, Maira Asare and Laima Muktupāvela. The stories in the collection are dedicated to significant historical events of the twentieth century in Latvia. They simultaneously tell both the collective history and outline the wide range of differences of the individual experience. Stories are very different - from precise autobiographical memories to authentic frame-ups. Stories mostly synthesize two historical perspectives - the historical time of the event marked by the language stylization of the depicted time, mention of the realia and certain clichés, stereotypes, signs of the epoch and the contemporary interpretation of this time. Therefore, reading these stories, occasionally there occurs a feeling that the writers wish to project events of the past on the present situation. For instance, Kristine Želve in the story "Days of the Soubrette" writes:

Today, coming from the theatre, there was a demonstration of the unemployed in the streets. Kviesis (15) made a speech over the radio that during a general illness and crisis of an organism all its constituent organs suffer severely, also the small Latvia, that everyone will do all that is possible for the illness and crisis not to be long and our dear Latvia to become a welfare country in a short time...(16).

The edition of the book is supplied with documentary or artistic photographs that characterize the epoch depicted by the authors.

(13) $[8,58]$.

(14) $[8,86]$.

(15) President of Latvia 1930-1934.

(16) $[13,90-91]$. 


\section{CONCLUSIONS}

The close affinities of the literature and the epoch, waves of individual and collective identity feelings, synthesis of refined and provoking expression form the background of the concepts 'Latvia' and 'Latvians' depicted in recent Latvian literature. In the first half of the 21 st century - the time of well-being of the state until the economic crisis of 2008 - Latvian writers took up depictions of personal identity manifestations thus emphasizing the significance of each individual's experience in public rites. The situation of crisis, however, intensifies the depictions of the collective identity in the Latvian literature, setting forth in fiction society or themes that unite its segments.

Received 24 April 2012 Accepted 25 September 2012

\section{References}

[1] ANKRAVA, Sigma. Postkoloniālisma sindroms un identitāte Latvijā. 2002 [last viewed 23.11.2011]. Available from: <http://www.tautasforums.lv/? $\mathrm{p}=1272>$

[2] BAN̦G̣IERE, Asnate. Latviešu viesstrādnieks Londonā uzraksta kulta romānu. 2010. Available from: <http://www.kasjauns.lv/lv/zinas/35026/latviesu-viestradnieks-londona-uzraksta-kulta-romanu>

[3] BERELIS, Guntis. Kokteilis, kas ir sprādzienbìstams. Saruna ar Otto Ozolu. 2010 [last viewed 18.04.2012]. Available from: <http://berelis.wordpress.com/2010/08/18/kokteilis-kas-ir-spradzienbistams-saruna-ar-otto-ozolu/>

[4] ËRIKSENS, Tomass Hillanns. Saknes un peedas. Identitāte mainīgā laikā. Rīga: Zvaigzne ABC, 2010.

[5] HALL, Stjuart. The question of cultural identity. In: Modernity: An Introduction to Modern Societies. S. Hall, D. Held, D. Hubert, K. Thompson (Eds.). Malden: Blackwell Publishing, 2006/1996, p. 595-634.

[6] IKSTENA, Nora. Par mums. Šokolādes Jēzus. Rīga: Dienas Grāmata, 2009.

[7] JUNDZE, Arno. Vilis Lācitis un latvju leibors. 2010 [last viewed 23.11.2011]. Available from: <http://zinas.nra.lv/izklaide/33149-vilis-lacitis-un-latvju-leibors.htm>

[8] LĀCĪTIS, Vilis. Stroika ar skatu uz Londonu. Rīga: Mansards, 2010.

[9] OZOLS, Otto. Latvieši ir visur. Rīga: Atēna, 2010.

[10] RAUBIŠKO, Ieva. Eiropa - materiālā vai konceptuālā? Eiropas Avīze [Vienreizējs bezmaksas izdevums], 2011. Gada 9. maijā, 4. lpp.

[11] RUDAKS, Uldis. Pirmizrāde Viḷa Lācī̌sa romāna Stroika ar skatu uz Londonu iestudējumam. 2011. Gada 6. aprīlis [last viewed 23.11.2011]. Available from: <http://www.diena.lv/izklaide/ skatuve/pirmizrade-vila-lacisa-romana-stroika-ar-skatu-uz-londonu-iestudejumam-774554>

[12] ŠĶILTERS, Jurğis. Nacionālā identitāte semantiskajā telpā. Nacionālās identitātes komunikācija Latvijas kultūras telpā. Jurğa Šḳiltera un Skaidrītes Lasmanes redakcijā. Rīga: Latvijas Universitātes Sociālo un politisko pētijumu institūts, 2011.

[13] ŽELVE, Kristīne. Subretes dienas. XX gadsimts. Mēs. Rīga: Dienas Grāmata, 2011. 
MAIJA BURIMA

\section{Latvijos ir latvių vaizdavimas šiuolaikinèje latvių literatūroje}

Santrauka

„Latvija“ ir „latviai“ yra labiausiai su kultūros politikos tendencijomis ir istoriniais bei socioekonominiais pokyčiais susijusios sąvokos literatūroje. Latvių literatūroje nèra daug tekstų, kuriuose daugiausia dèmesio būtų skiriama latvių tautai ir valstybei kaip reiškiniui.

Straipsnyje analizuojami nacionalinès / valstybinès tapatybès vaizdavimo atvejai kaip pagrindinès strateginès apraiškos šiuolaikinejje latvių literatūroje. Sudètingais ar dramatiniais momentais tautos / valstybès istorijoje ši strategija suaktyveja. Dabartinejje latvių literatūroje pabrèžiami du tapatybès aspektai: asmeninė tapatybè - individualus savęs suvokimas, grindžiamas asmens fizinèmis, intelektinemis ir moralinèmis savybèmis, ir grupinè ar socialinè tapatybè - individualios asmeninès savybès, grindžiamos priklausymu konkrečioms socialinèms grupèms - etninei, profesinei ir t. t. Viename literatūriniame kūrinyje gali būti vaizduojama tiek viena, tiek ir keletas tapatybių.

XXI a. 1-2-ojo deš. sandūroje išleista nemažai tekstų, kurių pavadinimuose pabrèžiami leksiniai vienetai „latviai“, „mes“ ar kai kurie svarbūs nacionalinės kultūros ženklai. Keletas grožinès literatūros kūrinių, kurių pavadinimai suponuoja bendras socialines ir mentalines šiuolaikinès Latvijos visuomenès struktūras kaip tapatybès bendruomenių egzistavimo prielaidas, plačiai nušviečia kolektyvinès tapatybès aspektus.

Tarp šiame darbe analizuojamų tekstų - Karlio Verdinio (Kārlis Vērdiņš) poetinès prozos rinkinys $A \check{s}(E s)$ (2008), Guntaro Godinio (Guntars Godiņ̌̌) poezijos rinkinys CV, Noros Ikstenos apybraiža Apie mus (Par mums) (2009), Vilio Lacičio (Vilis Lācītis) romanas Statybų aikštelè su vaizdu į Londoną (Strojka ar skatu uz Londonu) (2010), Oto Ozolo (Otto Ozols) romanas Latviai yra visur (Latvieši ir visur) (2010). Raktažodžiai: tapatybė, asmeninè tapatybè, kolektyvinè tapatybė, Latvija, latviai 